UNIO - EU Law Journal. Vol. 4, No. 1, January 2018, pp 45-50.

®2018 Centre of Studies in European Union Law

School of Law - University of Minho

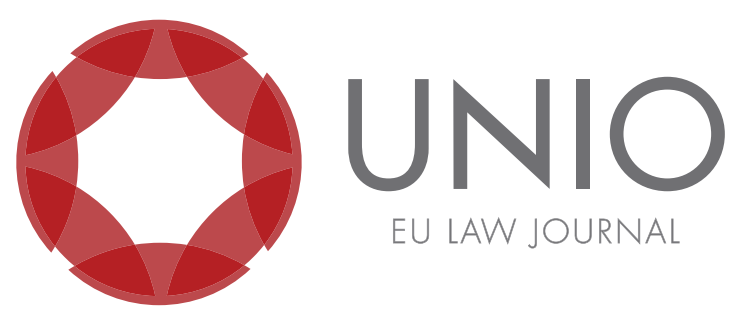

\title{
The globalisation of the Judicial Power - context and challenges
}

José Igreja Matos*

ABSTR ACT: Judicial Independence today is facing, particularly in Europe, new threats emerging from populist political regimens. After a structural analysis of the main constraints to the upholding of an independent judiciary, some indications are listed, in a very brief note, to better affirm, at the level of the judiciary, the values of Democracy and Rule of Law, assuming an "ethics of practical responsibility".

KEYWORDS: judges - globalisation - judicial independence - rule of law-judicial etbics.

\footnotetext{
* President of the European Association of Judges (EAJ). Vice-President of the International
} Association of Judges (IAJ). 
An old Chinese proverb, frequently quoted in our times, alerts for the dissimulated dangers of the so called "interesting times" normally announcing, in fact, troublesome moments.

The present article, arguably simple and short, will be founded precisely on this sense of distress that the European judiciary is currently under.

Accepting the fundamental axiom that, in a State sustained by the Rule of Law, it is always up to the Courts to guarantee the effectiveness of human rights, there is a strong operative connexion between the exercise of human rights - or the correspondent imposition of duties - and the mission conducted by the judicial systems.

This detected closeness explains that the present decline of judicial independence in different regions represents a clear symptom of the detachment by the related States towards its commitment to democratic values. In fact, it is interesting to identify how, in recent European experience, the arrival of new totalitarian regimes , since the very early stages, has instigated an immediate and vigorous attack on the independence of the judiciary, propelled by surgical legislative reforms in the area of Justice.

For this very reason, the difficult situation that crosses the Judiciary, particularly in the framework of political systems that have opted for a populist drift - with the recent examples of Turkey, Poland, Bulgaria, or Romania - draws a tangible crisis of Rule of Law, in general. Knowing too well how the continuous decline into disastrous policies led the Old Continent to fratricidal struggles in a recent past, an energetic alert for this withdrawal of our civilization is indispensable at the present historical crossroad.

It is now, like always, important to claim that the Judiciary is a pivotal factor in the affirmation of human rights guaranteeing its implementation far beyond a mere grandiloquent and innocuous statement of intentions.

In this regard, Wittgenstein used to voice an episode with a friend anthropologist who had studied the habits of a specific tribe in Africa. In this tribe, a concrete game was played assiduously; but when he asked which rules were applicable, none of them were able to explain. After a prolonged and attentive observation, the anthropologist himself was the first to define, in writing, the rules of this game, describing them. From that moment, two types of people appeared in that society: those who knew how to play and those who also knew the rules of the game.

In this comparison, the Judiciary will be precisely the organization which, besides knowing how to play - having a notion, even if intuitive, of what human rights imply - also has the power, grounded on mandatory rules, to sanction those who ignore or evade those expressed norms.

We all feel we know what the "game" is about but only the Judiciary provides the due enforcement, applying the rules defined as normative impositions.

The acknowledgment of the importance of judicial systems also endogenously is enhanced by the relevance attributed to the procedural dimension of courts, largely founded on a democratic debate, rational and argumentative, built on a plural and open rationality that embraces complexity without demonizing it. This "dialogue of reason", in a symbolically assumed forum with a specific timeframe, distant from frenetic media timings, legitimates the very essence of the Judiciary and personifies one of its most valuable assets.

The uniqueness of courts, in the described founding themes, will, therefore, be 
unequivocal.

But within a framework of the globalisation of law, what major contemporary threats to the Judiciary are impending - mainly in Europe in the present times - ?

In an effort of synthesis, one could find structural dangers affecting the Judiciary. First of all, in the total "capture" of judicial systems, for instance in regions of Latin America for organized crime in particular related to the various traffics of drugs, weapons or persons, or, in a similar perspective, the submission of judicial systems to dictatorships, in countries like Venezuela or Turkey.

The assumed "divorce" between courts and citizens must also be listed as a second example of a menace for the Judiciary. A phenomenon that is transversal to many Judiciaries in several continents, it erupts, with emphasis on some of them, initiating a wear and tear in relations with the community that definitively alienates the essential value of trust, indispensable to the harmonious functioning of any judicial system.

It could be said that a citizen does not seek the court because he does not find any answer there or even because he/she is simply not aware of its possible response. Such apathy induces a general ineffectiveness, leading to a persistent and underlying malaise.

In the described context, problems connected with unreasonable decision delays and the violations of the right to a decision within reasonable time are highlighted.

Finally, the third factor of deprivation of the Judiciary has to do with budgetary constraints. It is clear that an adequate financial funding is a conditio sine qua non for court activities to be performed with quality and efficiency. At this level, for example, it can be listed the reform of the judicial system in United Kingdom, where there has been a drastic reduction of $f, 220$ million in the budget for legal aid, which means that the diminution of real advice and assistance to the economically disadvantaged citizens. In addition, a recent Belgian Government proposal for a reduction in the budget for Justice of an impressive 10\% within 4 years is also worth highlighting in this regard. The continued erosion of the remuneration status of judges, particularly in countries such as Portugal and Greece, is another significant obstruction to a prestigious and acting Judiciary.

This last scenario should not be mistaken with the previous one since, in this latter case, the judicial system, as a whole, emerges as independent, possibly even with social empathy and a relation of trust with the people, but simultaneously it is becoming increasingly inoperative.

It can be affirmed that the reported structural obstacles now presented, in their tripartite division, have a close analogy with some radical erosion phenomena that summon the geological metaphor, emulating, in this sense, the thematic of the evolution of constitutionalism and the emergence of the concept of interconstitutionalism. Thus, according to Professor J.J. Gomes Canotilho, after the suggestion of J. Weiler in his "The geology of international law", constitutional science is matured through the phenomenon of accretion, that supposes a process by which it is gradually accumulated, in extension or volume, sedimentary material. In this metaphorical sense, the accumulation of sediments develops new stratifications, making Constitutional Law evolve. As the author explains, as, in geology, the science of constitutional law increases its "rock mass" as a result of a set of elements constitution theory, methodical rules, etc. - which represent the sedimentary strata of constitutional law. 
With the obvious risk of over-simplification, it will be interesting to add to the concept of accretion the notion of digenesis as a change in the sediment after its initial deposition, more profound and durable than a mere wear and tear, in such a way that a mineral data, existing in the sediments, rocks, and fossils, is replaced by other minerals, during the digenesis.

In this respect, especially on the international stage, occurrences such as globalisation, migrations, disseminated social media or even the new emerging populisms attracting potential dictatorial regimes are seen as indications of a rupture of a paradigm, i.e. the emergence of a larger phenomenon - that of digenesis - which grows more intensively and deeply than a simple accretion.

With the imprint of these new times - characterized by an era of post-states in the so-called "risk societies". ${ }^{1}$ It is, therefore, cardinal that Judiciaries can adjust and establish new concepts, procedures, and attitudes as factors for a required change and adaptation. In the end, having in mind the words of Saint-Exupéry for the ultimate purpose of any professional pursuit: "the grandeur of a profession is, above all, (...) uniting men".

As to the factors that could imply a new valuable approach for judiciaries in Europe, I will now specify four guidelines that could be foreseen.

The so-called "dialogue of judges in globalization" characterizes the first one.

Undeniably, the intensification of global interdependencies produces the deterritorialization of social relations and causes a multiplication - essentially positive - of claims for rights of a supranational nature; precisely following this evolution arises what Antoine Garapon calls "the globalization of the judges". ${ }^{2}$ This global dialogue of judges can take the most diverse forms ranging from the vertical relationship - in the case of the creation and empowerment of supranational courts - to the horizontal relationship based on an operational, open and interdisciplinary cooperation, perhaps the one that most directly address us in the present context.

At the same time, the active and committed participation of academia as a whole should be stimulated in the task to consolidate a concrete implementation of Human Rights.

Following José Joaquim Gomes Canotilho's lesson, a second crucial path is the substitution of an ethic of conviction for an ethic of practical responsibility that definitively moves off from the "grandiloquence in words" always accompanied by "the weakness of the acts" as characteristic of the former. The presence in civil society of an obligation to pursue a more engaged commitment to ethics in public life, particularly at the level of the professions, not only in politics but also in the courts, is now undeniable in a movement that began in the last decades of the twentieth century.

Then, as a "setting" for any project of the future, it will remain mandatory that the achievement of real Judicial Independence, assumed as a duty of all the Powers of the State, public and unambiguous, arrayed, not in counterpoint but in complement on effective mechanisms of integrity and accountability by the Judiciary.

The rule of law demands, in the present troubled times, a serene but explicit choice by international political institutions. In the case of the European Commission, the triggering of Article 7 of the Treaty on European Union in response to recent legal reforms in Poland, which in practice threatens the independence of the Judiciary

${ }^{1}$ Ulrich Beck, Risk societies (London: Sage, 1992).

${ }^{2}$ Free translation. Antoine Garapon and Julie Allard, Les Juges dans la mondialisation (Paris: Le Seuil, 2005). 
in the country, contrasts, albeit timorously, with a complacent apathy that allowed, years ago, the present situation in Hungary, which was characterized by a docile and domesticated Judiciary, obedient to the momentary interests of the dominant political power.

Recently, in the context of the public appeal posed by the European Association of Judges, the European Commission's President Mr. Jean-Claude Junker stated in a written message that the European Commission is determined to defending the rule of law in all Member States as a fundamental principle, clarifying that an independent Judiciary is an essential requirement to be a member of EU and that the European Union will never accept a system that allows the dismissal of judges at will. Further, Mr. Junker explained that if the Polish Government pursues this legislative reform which undermines the independence of judges and the rule of law in Poland, in particular, if any action is taken to dismiss or force the retirement of judges of the Supreme Court, the Commission will immediately activate Article 7 of the Treaty on European Union, since there is a clear peril of a serious breach of the requisites referred to in Article 2 of the Treaty. Article 2 proclaims that the Union must be established upon the values of democracy, rule of law and respect for human rights.

The sanction provided for by Article 7 promulgates the option of suspending some of the rights of the respective Member State, including the right to vote of the representative of the Government of that Member State in the Council. However, the condition of a unanimous vote by the other Member States to enforce this type of sanctions is undoubtedly compromised by the well-known position of Hungary.

In fact, there is today, a disturbing circumstance in the EU: the presence of Member States which, after having accepted the rules imposed by the Union to be admitted - in particular with regard to the building of an institutional and regulatory structure which can guarantee the conditions for the independence of the judicial power - have been dispossessed of them in such a way that, given the distinct legal framework, they could certainly not have been accepted now in the same Union. Even if the option of withdrawing the voting right to Poland will not be approved - although it seems that we cannot continue to relegate the essential nucleus of European values, particularly those which impose the separation of powers of the State and the independence of judges, to a secondary and expendable level - there must be always alternatives to be applied. In this context, it can be considered, in a negative approach, an imposition of a reduction in financial support for recalcitrant states or, on a more positive policy, to opt for a reinforcement of the investment of the European budget in the promotion, protection, and safeguarding of rule of law in the different Member States.

In Latin America - where problems of intromission with the judiciary greatly overshadow those recently occurring in Europe - the decision to initiate in the Southern Common Market (Mercado Común del Sur - MERCOSUR) the process of applying the Democratic Clause regarding Venezuela, due to the recent problematic developments in the country, must be praised.

Finally, in a fourth register, we share the conclusion that, in our days, a new concept of citizenship is required to transcend the classic definition focused exclusively at a state level, for a new one assumed to be cosmopolitan in the face of a political post-national reality. In this sense, citizenship must also be assumed as a group process, implying an engaged participation of NGOs, civil society associations or professional associations - such as the European Judges Association with its 
unyielding commitment to the values of judicial independence - which must actively complement each other. The plan is mainly to avoid an individual and necessarily secluded dimension of citizenship in a globalized world with regional threats.

But let's not be misled by an unfounded optimism.

The more recent times require resilience; they have been consistently treacherous for Human Rights, for an independent Judiciary and, in the end, for the upholding of our shared European values. In a recent survey of the 43 national associations that constitute the European Judges Association, the question: "Has the situation in your country's judicial system improved, worsened or remained stable in the last five years?" twenty of them responded negatively.

This perception corresponds to a deep and insurmountable feeling of disenchantment of judges in the face of the continuous aggravation of the conditions for the exercise of their functions, characteristic of a widespread awareness that can be detected also in Portugal.

But the answer exists and it should necessarily occur.

Zygmunt Bauman, who, unfortunately, recently disappeared, warned that the solutions can never arise by the handling of magic wands; they require "a cold head, nerves of steel and a lot of courage: above all, we will need a truly long-term vision - and a lot of patience". ${ }^{3}$

In a reflection that also underlines the relevance of dialogue as claimed by Pope Francis ("if there is a word we should never be tired of repeating is the word dialogue") it is time, once again, to focus on what really matters for judicial systems to serve the people, the primary recipients of those who work daily in courts. Because the problems that we face require that we have concrete and real answers; as Bauman emphasizes, it is the proper moment to combine the concept of effectiveness with the definition of policies that are truly "human".

In this long-term, patient and challenging combat with judicial professions, particularly judges, associated also on a transnational scale, must assume an almost inevitable leadership; with resilience in the affirmation of the values that defines our sworn commitment.

My final words will emulate the most reliable of all Arts and Poetry, by the melancholic inspired pen of Pablo Neruda on a rough translation:

"If every day falls, within each night

There is a well where the light is fastened,

You have to sit on the edge of the pit, in the shade

And catch the fallen light with patience."

\footnotetext{
${ }^{3}$ Free translation. Zygmunt Bauman, La grande regressione: Quindici intellettuali da tutto il mondo spiegano la crisi del nostro tempo (Milan: Feltrinelli, 2017), 50.

${ }^{4}$ Free translation. Pablo Neruda, "Si cada día cae", in Últimos poemas (São Paulo: L\&PM, 1997).
} 